\title{
Design and Discovery of a High Affinity, Selective and $\beta$-Arrestin Biased 5-HT7 Receptor Agonist
}

\section{Edem K. Onyameh}

Florida A\&M University

\section{Edward Ofori}

Florida A\&M University

\section{Barbara A. Bricker}

Florida A\&M University

Uma M. Gonela

Florida A\&M University

Suresh V. K. Eyunni

Florida A\&M University

Hye J. Kang

University of North Carolina at Chapel Hill

Chandrashekar Voshavar

Florida A\&M University

Seth Y Ablordeppey ( $\nabla$ seth.ablordeppey@famu.edu )

Florida A\&M University https://orcid.org/0000-0003-0174-1153

\section{Research Article}

Keywords: 5-HT7 receptor, indanone, tetrahydroisoquinoline, $\beta$-arrestin-biased ligand, 5-HT7R agonist, eutomer

Posted Date: July 8th, 2021

DOI: https://doi.org/10.21203/rs.3.rs-648176/v1

License: (c) (i) This work is licensed under a Creative Commons Attribution 4.0 International License. Read Full License

Version of Record: A version of this preprint was published at Medicinal Chemistry Research on September 23rd, 2021. See the published version at https://doi.org/10.1007/s00044-021-02797-4. 


\section{Design and discovery of a high affinity, selective and $\beta$-arrestin biased $5-\mathrm{HT}_{7}$ Receptor Agonist}

Edem K. Onyameh, ${ }^{1}$ Edward Ofori, ${ }^{1,2}$ Barbara A. Bricker, ${ }^{1}$ Uma M. Gonela, ${ }^{1}$ Suresh V. K. Eyunni, ${ }^{1}$ Hye J.

Kang ${ }^{3,4}$ Chandrashekar Voshavar ${ }^{1}$, Seth Y. Ablordeppey ${ }^{1, \bigotimes}$

Seth Y Ablordeppey

seth.ablordeppey@famu.edu

Edem K. Onyameh

edemonyameh@gmail.com

Edward Ofori

eddy.pharm1985@gmail.com

Barbara A. Bricker

barbara.bricker@famu.edu

Uma M. Gonela

uma.gonela@famu.edu

Suresh V. K. Eyunni

suresh.eyunni@famu.edu

Hye J. Kang

gori7873@gmail.com

Chandrashekar Voshavar

chandra.voshavar@famu.edu

${ }^{1}$ Division of Basic Pharmaceutical Sciences, College of Pharmacy and Pharmaceutical Sciences, Florida A\&M University, Tallahassee, FL 32307, USA

${ }^{2}$ Present Address: College of Pharmacy, Chicago State University, 9501 S. King Dr., Douglas Hall, Chicago, Il 60626, USA

${ }^{3}$ Department of Pharmacology, School of Medicine, University of North Carolina at Chapel Hill, Chapel Hill, NC 27599-7365, USA

${ }^{4}$ National Institute of Mental Health Psychoactive Drug Screening Program (NIMH PDSP), School of Medicine, University of North Carolina at Chapel Hill, Chapel Hill, NC 27599-7365, USA 


\begin{abstract}
Compound 1c, 2-(2-(3,4-Dihydroisoquinolin-2(1H)-yl)ethyl)-5-fluoro-2,3-dihydro-1H-inden-1-one was previously reported from our laboratory showing high affinity binding to the $5-\mathrm{HT}_{7}$ receptor $(K i=0.5 \mathrm{nM})$. However, compound 1c racemizes readily upon enantiomeric separation. To prevent racemization, we have redesigned and synthesized a methyl and carboxyethyl analogs, compounds $\mathbf{2}$ and $\mathbf{3}$ respectively, whose binding affinities were similar to those of compound 1c. Compound $\mathbf{2}$ and $\mathbf{3}$ cannot undergo racemization since tautomerism was no longer possible and thus, compound $\mathbf{2}$ was selected for enantiomeric separation and further evaluation. Upon enantiomeric separation, the levorotatory enantiomer, (-)2 or $2 \mathbf{a}$ demonstrated a higher affinity and a $\beta$-arrestin biased functional selectivity for the 5- $\mathrm{HT}_{7}$ receptor. Although $\mathbf{2 a}$ showed 22 times less activity than 5-HT in the Gs pathway, it showed 28 times higher activity than 5 -HT in the $\beta$ arrestin pathway. This constitutes a significant $\beta$-arrestin pathway preference and shows $\mathbf{2 a}$ to be more potent and more efficacious than the recently published $\beta$-arrestin biased 3-(4-chlorophenyl)-1,4,5,6,7,8hexahydropyrazolo[3,4-d]azepine, the N-debenzylated analog of JNJ18038683 (Compound 7).
\end{abstract}




\section{Graphical Abstract}

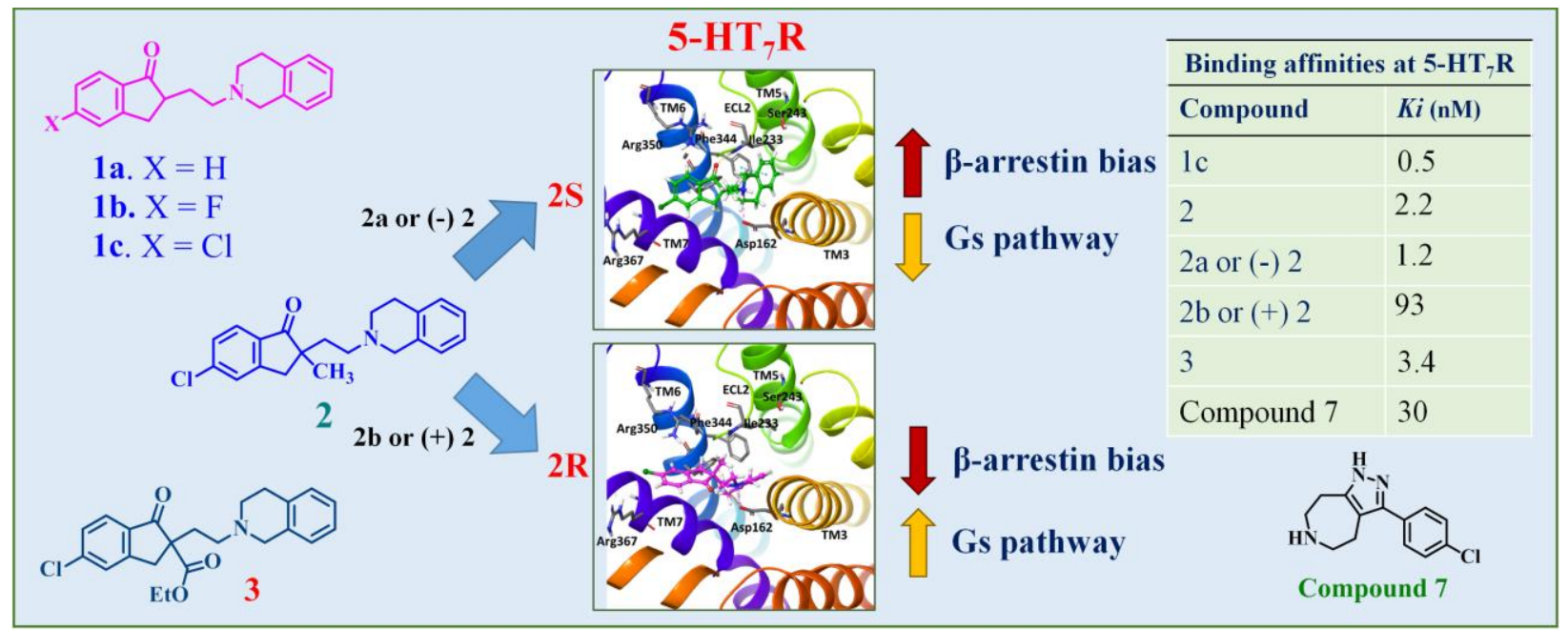

KEYWORDS: 5- $\mathrm{HT}_{7}$ receptor, indanone, tetrahydroisoquinoline, $\beta$-arrestin-biased ligand, $5-\mathrm{HT}_{7} \mathrm{R}$ agonist, eutomer 


\section{Introduction}

The serotonin-7 receptor $\left(5-\mathrm{HT}_{7} \mathrm{R}\right)$, the newest discovery of the 5-HTRs, is discretely localized in the thalamus, hypothalamus, cortical and limbic regions of the Central Nervous System (CNS) as well as in the periphery.[1,2] The pharmacology and therapeutic potential of the $5-\mathrm{HT}_{7}$ receptor and its involvement in several pathophysiological conditions have recently been reviewed.[3] Furthermore, several lines of evidence have implicated the role of $5-\mathrm{HT}_{7} \mathrm{R}$ in neuropsychiatric diseases including depression, pain, migraine, schizophrenia and disorders related to circadian rhythm.[4, 5] Studies have also shown that blockade or inactivation of the $5-\mathrm{HT}_{7} \mathrm{R}$ has led to antidepressant-like behavior.[6] These observations have led to the hypothesis that the 5-HT 7 R could serve as a new target for the design of drugs for the treatment of depression and other CNS diseases.[7]

SB-269970, JNJ18038683, and SB-258719 are 5-HT 7 R antagonists (Fig. 1) that have served as primary tools for the pharmacological characterization of the 5-HT 7 R.[8, 9] In addition, the selective 5-HT $\mathrm{R}$ agonists AS-19,[10] E-55888, LP-12, LP-44, and Compound 7 (Fig. 1) have been used to characterize the involvement of the 5-HT7 $\mathrm{R}$ in CNS conditions including memory and cognition.[11] More recently, it has been suggested that $5-\mathrm{HT}_{7} \mathrm{R}$ agonists may be useful in the treatment of alcohol and drug abuse.[12] Furthermore, there have been efforts to identify new agents that not only show selectivity for the $5-\mathrm{HT}_{7} \mathrm{R}$, but also display signaling bias to allow for further characterization of the 5-HT 7 R. $[13,14]$ Our lab began a focus on identifying new, high affinity $5-\mathrm{HT}_{7} \mathrm{R}$ ligands $[15,16]$ that might find utility in treating some of the cognitive symptoms of schizophrenia and especially identifying new ligands that display a bias for the signaling pathways at the $5-\mathrm{HT}_{7} \mathrm{R}$. In this, we report the discovery of (-)-5-chloro-2-(2-(3,4dihydroisoquinolin-2(1H)-yl)ethyl)-2-methyl-2,3-dihydro-1H-inden-1-one (2a) as a selective and $\beta$-arrestin biased $5-\mathrm{HT}_{7} \mathrm{R}$ agonist for use as a pharmacological tool for further probing the $5-\mathrm{HT}_{7}$ receptor. 


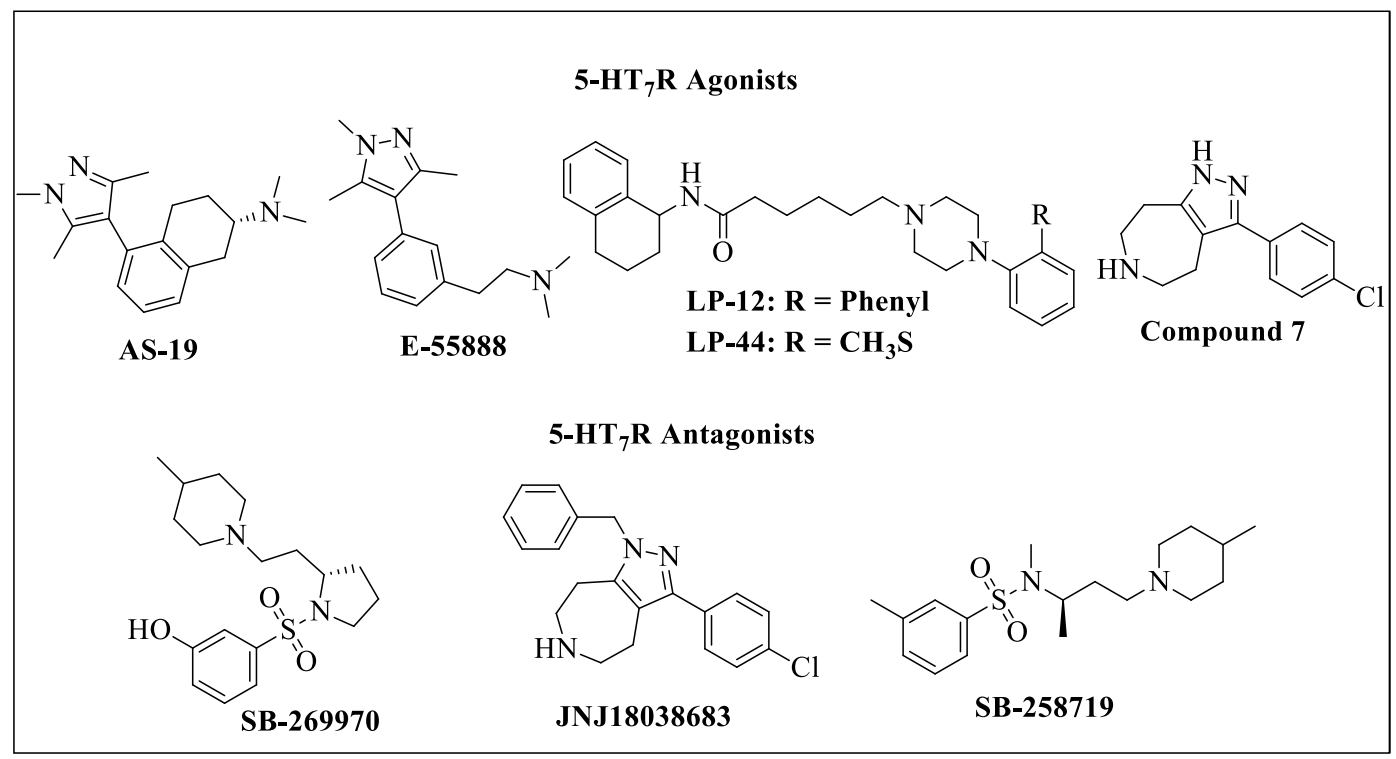

Fig. 1 Some $5-\mathrm{HT}_{7}$ receptor agonists and antagonists reported in the literature.

We have previously reported the synthesis and evaluation of the binding affinities of compounds 1a-c, with 1c, 2-(2-(3,4-dihydroisoquinolin-2(1H)-yl)ethyl)-5-fluoro-2,3-dihydro-1H-inden-1-one (Fig. 2) having the highest affinity for the $5-\mathrm{HT}_{7}$ receptor $(K i=0.5 \mathrm{nM}) .[16]$ However, these indanone and tetrahydroisoquinoline (THIQ) linked analogs (1a-c) have a chiral center and the resulting enantiomers may differentially bind to the $5-\mathrm{HT}_{7} \mathrm{R}$. Thus, it was of interest to separate the enantiomers of $1 \mathrm{c}$ and identify the eutomer to ascertain any such differential binding affinity and consequently their pharmacological action.

Using chiral chromatographic columns, we have been able to separate the enantiomers, but the isolated enantiomers were unstable even at a neutral $\mathrm{pH}$ and quickly reverted to the racemic mixture in a matter of hours. Thus, there was a need to redesign a new agent that could not undergo racemization and yet retain its binding affinity to the $5-\mathrm{HT}_{7} \mathrm{R}$. To accomplish this goal and to obtain analogs that retain selective binding to 5- $\mathrm{HT}_{7} \mathrm{R}$, we designed and synthesized 5-chloro-2-(2-(3,4-dihydroisoquinolin-2(1H)-yl)ethyl)-2-methyl-2,3dihydro-1H-inden-1-one (2) by replacing the acidic alpha proton with a methyl group and later, by a 
carboxyethyl group to obtain ethyl 5-chloro-2-(2-(3,4-dihydroisoquinolin-2(1H)-yl)ethyl)-1-oxo-2,3dihydro-1H-indene-2-carboxylate (3).
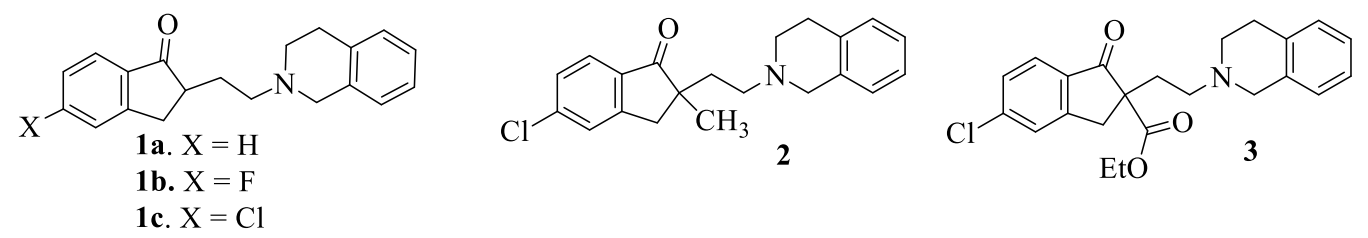

Fig. 2 Chemical structures of 5-HT7R ligands (1a-c, 2 and 3)

\section{Results and Discussion}

\section{Chemistry}

To obtain compound $\mathbf{2}$, the commercially available 5-chloroindanone $\mathbf{5 a}$ was treated with sodium hydride $(\mathrm{NaH})$ and then diethyl carbonate to produce a $\beta$-keto ester $\mathbf{5 b}$ as reported in Scheme $\mathbf{1}$. Compound $\mathbf{5 b}$ was reacted with $\mathrm{NaH}$ and iodomethane to deliver a methyl group at the $\alpha$-carbon of the $\beta$-keto ester, 5c. The methylated ester 5c was hydrolyzed and decarboxylated using acetic acid and concentrated $\mathrm{HCl}$ in a microwave assisted synthesis (MWAS) to afford ketone 5d. The ketone 5d was reacted with NaH and 1bromo-2-chloro ethane to produce the alkylating agent 5e which was then coupled to 1,2,3,4-tetrahydroisoquinoline (THIQ) under a general alkylating condition to afford the final product, $\mathbf{2}$ as a racemate. NMR and Elemental (CHN) analysis confirmed the product as the desired compound.

Compound 2 satisfies all the criteria for Lipinski's rule of five (Ro5) [17] except for the ClogP value of 5.2. Given the relatively high CLogP value, additional analog was designed to reduce the CLogP value by replacing the lipophilic methyl group with carbethoxy group to form compound $3(\mathrm{C} \operatorname{LogP}=4.42)$, thus ensuring that this analog fully satisfy the Ro5.

The synthesis of $\mathbf{3}$, (Scheme $\mathbf{2}$ ), began with intermediate $\mathbf{5 b}$ obtained in Scheme $\mathbf{1}$, by initially treating with $\mathrm{NaH}$ followed by 1-bromo-2-chloroethane to form alkylating agent $\mathbf{6 a}$. Intermediate $\mathbf{6 a}$ was used to alkylate 
the commercially available 1,2,3,4-tetrahydroisoquinoline (THIQ) under a microwave assisted condition to deliver the desired product, ethyl 5-chloro-2-(2-(3,4-dihydroisoquinolin-2(1H)-yl)ethyl)-1-oxo-2,3-dihydro1H-indene-2-carboxylate, 3 which was subsequently converted to the oxalate salt.

\section{Enantiomeric Separation}

The enantiomers of 2 were separated using high performance liquid chromatography (HPLC) with a semiprep scale CHIRALPAK AD-H as reported previously. [18] Reinjection of the separated enantiomers on an analytical scale CHIRALPAK AD-H HPLC column indicated $100 \%$ enantiomeric purity for (-)2 (2a) and $100 \%$ enantiomeric purity for $(+) \mathbf{2}(\mathbf{2 b})$. No racemization was subsequently observed, and the enantiomeric purity remained at $100 \%$. Evaluation of the enantiomers in a Jasco P-1020 polarimeter at an average cell temperature of $23.5^{\circ} \mathrm{C}$ and a wavelength of $589 \mathrm{~nm}$ indicated that the specific rotations [ $\alpha$ ] for the free base forms in ethanol were $[\alpha]_{\mathrm{D}}^{23.5}(c 1.44, \mathrm{EtOH})=(-) 86.2$ for $\mathbf{2 a}$ and $[\alpha]_{\mathrm{D}}^{23.5}(c 1.49, \mathrm{EtOH})=(+) 93.3$ for $2 \mathbf{b}$.

\section{Biological Evaluation}

Having obtained the first desired target compound (2) and its enantiomers (-)2 or $\mathbf{2 a}$ and (+) $\mathbf{2}$ or $\mathbf{2 b}$, the compounds were sent to the Psychoactive Drug Screening Program (PDSP) to screen for binding at relevant CNS receptors. The results are reported in Tables 1 and 2.

Table 1. Binding affinities of compound 2 and enantiomers at 5-HT receptors and SERT Transporter

\begin{tabular}{|c|c|c|c|c|c|c|}
\hline \multirow{2}{*}{ Compound } & \multicolumn{6}{|c|}{ *Binding affinity constants, $\mathrm{pKi} \pm \mathrm{SEM}(K i \mathrm{nM})$} \\
\hline & 5-HT $1 \mathrm{~A} R$ & 5-HT $2 \mathrm{~A} R$ & $5-H_{2 B} R$ & $5-H_{2} \mathrm{CR}$ & 5-HT 7 R & SERT \\
\hline 2 & $5.87 \pm 0.27(1718)$ & $6.06 \pm 0.06(904)$ & $6.79 \pm 0.05(174)$ & $5.86 \pm 0.07(1735)$ & $8.65 \pm 0.07(2.2)$ & MTA \\
\hline 2a. [(-) 2] & $7.06 \pm 0.07(86.3)$ & $6.08 \pm 0.06(834)$ & $6.48 \pm 0.04(329)$ & MTA & $8.94 \pm 0.06(1.2)$ & MTA \\
\hline Clozapine & NR & NR & NR & NR & $8.30 \pm 0.08(5.0)$ & NR \\
\hline${ }^{\#} \mathrm{AS}-19$ & $(89.7)$ & NS & NS & NS & $(0.60)$ & NS \\
\hline
\end{tabular}

*The binding affinity results are reported as mean \pm SEM from a minimum of 3 independent assays, each in triplicates. \#Reported in ref 10 as a partial agonist with selectivity $>100$ fold at all 5-HTRs except for $5-\mathrm{HT}_{1 \mathrm{D}} \mathrm{R}(\mathrm{Ki}=6.6 \mathrm{nM})$. \% Reported in ref 14 as compound 1g. MTA = Missed threshold of 50\% inhibition at $10 \mu \mathrm{M}$ concentration. NR = Not reported; NS = Not significant 
Compared to the standard drug clozapine, 2 binds with a 2 -fold higher affinity at the $5-\mathrm{HT}_{7} \mathrm{R}(K i=2.2 \mathrm{nM})$ and a 2-fold lower affinity than AS 19, a standard 5- $\mathrm{HT}_{7} \mathrm{R}$ agonist. Compound 2 also shows selectivity for the $5-\mathrm{HT}_{7} \mathrm{R}$ when compared to other 5-HTRs, Dopamine (DA) receptors and the three monoamine transporters (SERT, DAT and NET) evaluated. The eutomer or the (-) enantiomer, 2a, was selective by over 100-fold for all the receptors and transporters evaluated except for the 5- $\mathrm{HT}_{1 \mathrm{~A}} \mathrm{R}$ where the selectivity is greater by 20 -fold. The (+) enantiomer or the distomer $(\mathbf{2 b})$ has a 25 -fold less affinity for the $5-\mathrm{HT}_{7} \mathrm{R}$ and in fact, has a higher affinity for the $5-\mathrm{HT}_{1 \mathrm{~A}} \mathrm{R}(K i=376 \mathrm{nM}), 5-\mathrm{HT}_{2 \mathrm{~A}} \mathrm{R}(K i=729 \mathrm{nM})$ than for the $5-\mathrm{HT}_{7} \mathrm{R}(K i$ $=93 \mathrm{nM})$.

Table 2. Evaluation of the binding affinities of compound 2 and its enantiomers at DA receptors and other Monoamine Transporters (NET, DAT)

\begin{tabular}{|l|c|c|c|c|c|c|c|}
\hline \multirow{2}{*}{ Compound } & \multicolumn{5}{|c|}{$*$ Binding affinity constants, $\mathrm{pKi} \pm$ SEM $(\mathrm{Ki} \mathrm{nM})$ of ligands at DARs, NET and DAT } \\
\cline { 2 - 8 } & $\mathbf{D}_{\mathbf{1}}$ & $\mathbf{D}_{\mathbf{2}}$ & $\mathbf{D}_{\mathbf{3}}$ & $\mathbf{D}_{\mathbf{4}}$ & $\mathbf{D}_{\mathbf{5}}$ & NET & DAT \\
\hline $\mathbf{2}$ & MTA & $5.91 \pm 0.06(1225)$ & $6.76 \pm 0.06(185)$ & $6.01 \pm 0.06(1223)$ & MTA & MTA & MTA \\
\hline 2a. $[(-)$ 2 $]$ & MTA & MTA & MTA & $6.34 \pm 0.07(457)$ & MTA & MTA & MTA \\
\hline 2b. $[(+)$ 2 $]$ & MTA & MTA & $6.0 \pm 0.1(996)$ & MTA & MTA & MTA & MTA \\
\hline
\end{tabular}

MTA $=$ Missed threshold of $50 \%$ inhibition at $10 \mu \mathrm{M}$ concentration. *The binding affinity results are reported as mean \pm SEM from a minimum of 3 independent assays, each in triplicates.

\section{Molecular Modeling}

To evaluate compound interactions with 5- $\mathrm{HT}_{7} \mathrm{R}$ using AS-19, 2a, and $\mathbf{2 b}$ which have bias for recruiting $\beta$ arrestin to the $5-\mathrm{HT}_{7} \mathrm{R},[13]$ we selected a homology model of the 5-HT $7 \mathrm{R}$ published by Kim et al, 2018 [14] and the Induced Fit Docking (IFD) procedure was carried out using default parameters. The resulting model was validated by docking AS-19 into the model and replicating the appropriate interactions of the amino acid residues at the orthosteric site (Fig. 3) as reported [14]. To explore the difference in binding affinities and to predict which enantiomer (i.e., $2 \mathrm{~S}$ or $2 \mathrm{R}$ ) interaction is consistent with the binding affinities and $\beta$ arrestin recruitment, we evaluated the docking poses of the enantiomers in the homology model as shown in Fig. 4. 


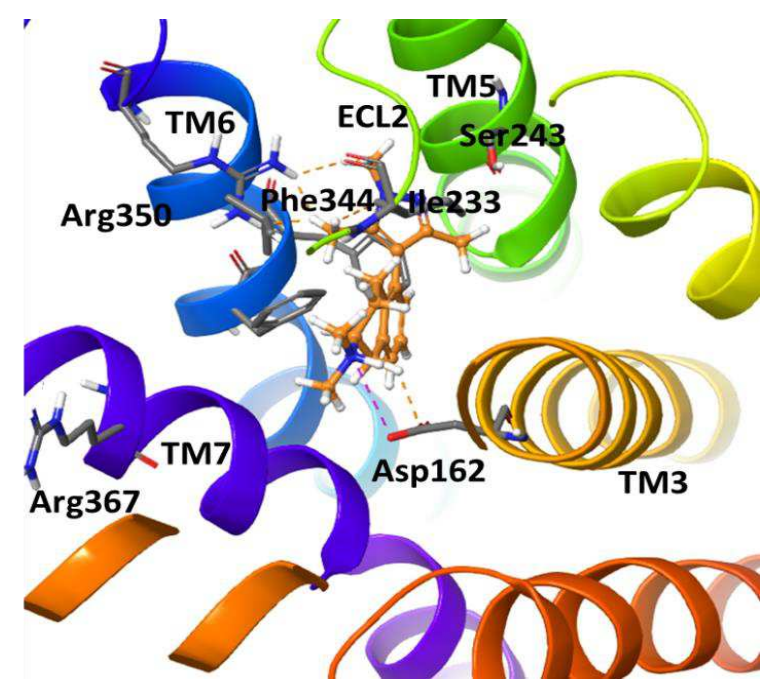

Fig. 3 Validation of the homology model of 5-HT 7 R obtained from Kim et al, 2018.[14] Compound AS-19 was docked into the model using induced-fit docking as implemented in Schrodinger's Small-Molecule Drug Discovery suite.[19-23] The observed interactions with the key amino acid residues Asp 162 and Ile 233 and not Ser 243 are confirmatory
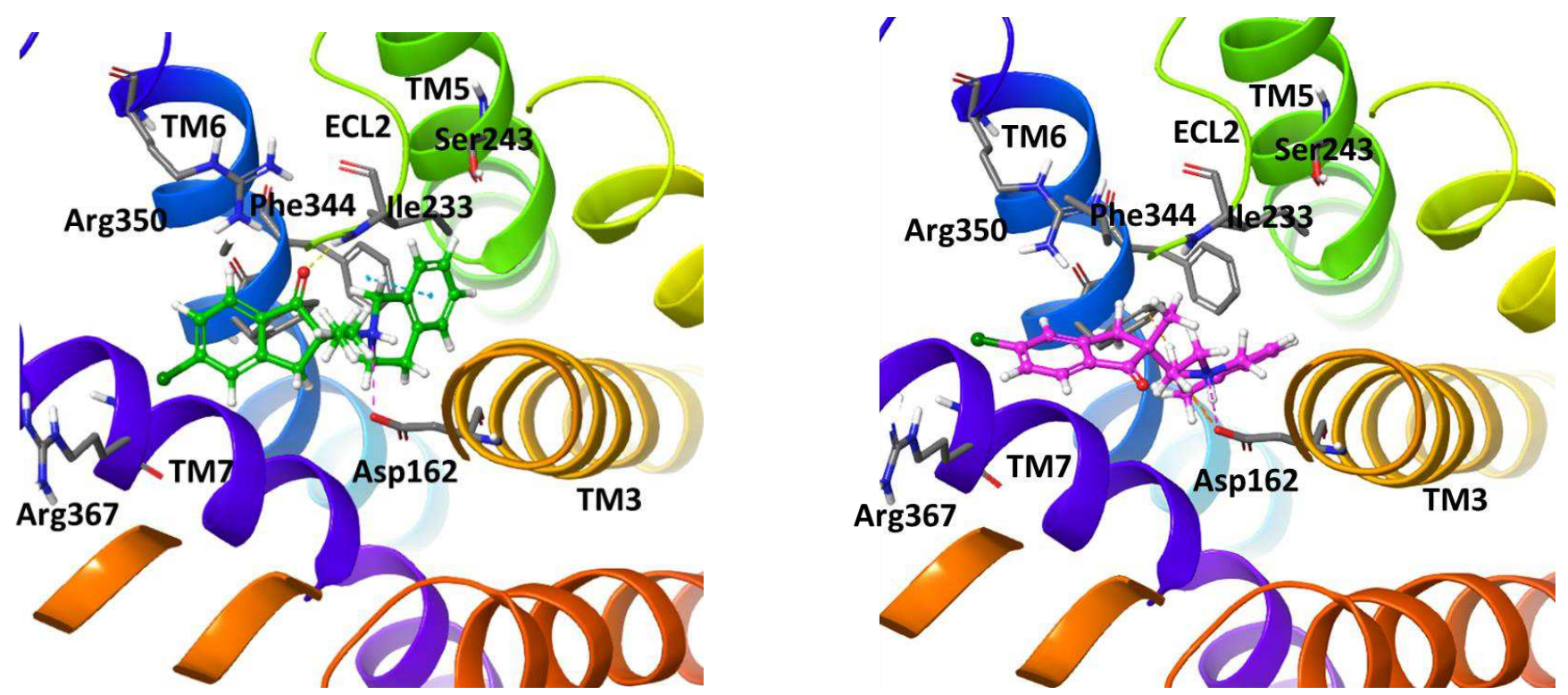

Figs. 4 (left) and 5 (right). Induced-fit molecular docking mode of $2 \mathrm{~S}$ and $2 \mathrm{R}$-enantiomers respectively at the orthosteric site of 5-HT $\mathrm{HT}_{7} \mathrm{R}$. The $2 \mathrm{~S}$ enantiomer interacts with Asp 162 and Ile 233 but not Ser 243, suggesting the capacity to recruit $\beta$-arrestin to the 5- $\mathrm{HT}_{7} \mathrm{R}$. In Fig. 4 (right), the $2 \mathrm{R}$ enantiomer could only make an interaction with Asp 162 but not Ile 233 or Ser 243.

Evaluation of the interactions of $\mathbf{2 S}$ at the orthosteric site of the $5-\mathrm{HT}_{7} \mathrm{R}$ revealed interactions with the key amino acid residues associated with $\beta$-arrestin biased signaling.[14] Thus, 2S has an ionic interaction with 
Asp 162, hydrogen bond interaction with Ile 233 through the oxygen of the carbonyl group but no interaction with Ser 243; these results are consistent with the interactions associated with $\beta$-arrestin recruitment as reported.[14] On the other hand, 2R had interaction with Asp 162, but no interaction with Ile 233 or Ser 243 , leading to its prediction to have little or no $\beta$-arrestin recruitment capabilities.

\section{Functional Studies}

The enantiomers of $\mathbf{2}$, i.e., $\mathbf{2 a}$ or the (-) enantiomer, and $\mathbf{2 b}$, the (+) enantiomer were selected for evaluation for functional selectivity at the $5-\mathrm{HT}_{7} \mathrm{R}$. The ligands were tested using both Gs-mediated cAMP production assay and $\beta$-arrestin recruitment tango assays in parallel and the results are reported in Table $\mathbf{3}$.

Table 3. Evaluation of the Functional Selectivity of Compounds 2a and $2 \mathrm{~b}$ at the 5-HT Receptor $^{-}$

\begin{tabular}{|c|c|c|c|c|c|c|c|}
\hline \multirow{3}{*}{$\begin{array}{l}\text { *Compound/ } \\
\text { Activity }\end{array}$} & \multicolumn{7}{|c|}{ 5-HT 7 Receptor } \\
\hline & \multirow{2}{*}{$\frac{\text { Binding }}{\mathbf{p K}_{\mathrm{i}},\left(K_{i}, \mathbf{n M}\right)}$} & \multicolumn{3}{|c|}{ cAMP } & \multicolumn{3}{|c|}{$\beta$-arrestin } \\
\hline & & Emax \% & $\mathrm{pEC}_{50},\left(\mathrm{EC}_{50}, \mathrm{nM}\right)$ & Hill & Emax \% & $\mathrm{pEC}_{50},\left(\mathrm{EC}_{50}, \mathrm{nM}\right)$ & Hill \\
\hline $2 a$ & $8.7 \pm 0.1(2.4)$ & $82.8 \pm 2.6$ & $6.9 \pm 0.3(126)$ & $1.3 \pm 0.2$ & $78.7 \pm 5.7$ & $8.4 \pm 0.1(3.98)$ & $1.2 \pm 0.1$ \\
\hline 2b, Agonist & \multirow{3}{*}{$7.1 \pm 0.2(80.7)$} & ND & ND & ND & $43.2 \pm 9.0$ & $6.8 \pm 0.2(158)$ & $1.0 \pm 0.1$ \\
\hline 2b, Inv Agonist & & $-4.8 \pm 2.2$ & $6.7 \pm 0.1(203)$ & $1.15 \pm 0.2$ & ND & ND & ND \\
\hline 2b, Antagonist & & 100 & $6.4 \pm 0.1(406)$ & $1.9 \pm 0.2$ & ND & ND & ND \\
\hline 5-HT & $8.9 \pm 0.2(1.3)$ & 100 & $7.8 \pm 0.1(15.3)$ & $.0 \pm 0.1$ & 100 & $6.9 \pm 0.1(125)$ & $3.4 \pm 0.4$ \\
\hline${ }^{\#}$ Compound 7 & $7.5 \pm 0.1(30)$ & 94.7 & $5.1 \pm 0.1(7788)$ & NR & 62.7 & $6.8 \pm 0.2(162)$ & NR \\
\hline
\end{tabular}

*Enantiomers (2a and 2b) were tested in both Gs-cAMP and $\beta$-arrestin recruitment (Tango) assays and the results are reported as mean \pm SEM from a minimum of 3 independent assays, each in triplicates. \#Data was obtained from ref 12 . NR $=$ Not reported. $\mathrm{ND}=$ Experiment was conducted but no antagonism was measured; NA = Experiment was not conducted

The results show that the (-) enantiomer $\mathbf{2 a}$ activates both G-protein and $\beta$-arrestin mediated signaling but acts more so as a $\beta$-arrestin-biased agonist at the $5-\mathrm{HT}_{7} \mathrm{R}\left(\mathrm{EC}_{50}=3.98 \mathrm{nM} ; \mathrm{Emax}=78.7 \%\right)$. In fact, 2a has a higher binding affinity $(K i=1.2 \mathrm{nM})$, is much more potent and more efficacious at recruiting $\beta$-arrestin to the $5-\mathrm{HT}_{7} \mathrm{R}$ than Compound $7\left(K i=30 \mathrm{nM} ; \mathrm{EC}_{50}=162 \mathrm{nM}\right.$; Emax $\left.=62.8 \%\right)$, recently disclosed in the literature.[14] It is interesting to further note that $\mathbf{2 a}$ showed 22 times less activity than 5-HT for the Gs pathway, while it showed 28 times more activity than 5-HT in the $\beta$-arrestin pathway. The (+) enantiomer, 2b on the other hand, has over 30-fold weaker binding affinity at the $5-\mathrm{HT}_{7} \mathrm{R}$ and displays less activity in 
recruiting $\beta$-arrestin to the $5-\mathrm{HT}_{7} \mathrm{R}$ by 77 -fold. Taken together, these results will predict (-) $\mathbf{2}$ or $\mathbf{2 a}$ to correspond to the $2 \mathrm{~S}$ enantiomer while $(+) \mathbf{2}$ or $\mathbf{2 b}$ will correspond to the $2 \mathrm{R}$ enantiomer.

As indicated earlier, compound 3, with the carbethoxy replacement for the alpha methyl group, was designed to improve hydrophilicity and comply with Lipinski’s Ro5.[17] Compound 3 improved CLogP by 0.80 units to 4.42 and thus, satisfy Ro5 and was synthesized for screening. As shown in Tables $\mathbf{4}$ and $\mathbf{5}$, the presence of the carbethoxy group in place of the methyl group did not weaken binding affinity to the 5$\mathrm{HT}_{7} \mathrm{R}$ and in fact compound $\mathbf{3}$ has a similar binding affinity as compound $2(K i=3.4 \mathrm{nM})$ and even slightly better than that of clozapine $(K i=5.0 \mathrm{nM})$.

Table 4. Binding affinities of compound 2 and 3 at relevant 5-HTRs and SERT Transporter

\begin{tabular}{|c|c|c|c|c|c|c|}
\hline \multirow{2}{*}{ Compound } & \multicolumn{6}{|c|}{ *Binding affinity constants, $\mathrm{pKi} \pm \mathrm{SEM}(K i \mathrm{nM})$ of ligands at 5-HTRs and SERT Transporter. } \\
\hline & $5-H T_{1 A} R$ & $5-H^{2} T_{2 A} R$ & $5-H T_{2 B} R$ & $5-H T_{2} C R$ & 5-HT 7 R & SERT \\
\hline 2 & $5.87 \pm 0.27(1718)$ & $6.06 \pm 0.06(904)$ & $6.79 \pm 0.05(174)$ & $5.86 \pm 0.07(1735)$ & $8.65 \pm 0.07(2.2)$ & MTA \\
\hline 3. & $7.30 \pm 0.10(52)$ & $7.42 \pm 0.08(38)$ & $7.79 \pm 0.08(16)$ & $6.05 \pm 0.08(885)$ & $8.47 \pm 0.06(3.4)$ & MT \\
\hline
\end{tabular}
MT $=$ Missed threshold of $50 \%$ inhibition. $\mathrm{NR}=$ Not reported. $*$ The binding affinity results are reported as mean \pm SEM from a minimum of 3 independent assays, each in triplicates.

Table 5. Binding affinities of compounds 2 and 3 at other dopamine receptors NET and DAT

\begin{tabular}{|l|c|c|c|c|c|c|c|}
\hline \multirow{2}{*}{ Compound } & \multicolumn{5}{|c|}{$*$ Binding affinity constants, $\mathrm{pKi} \pm$ SEM $(\mathrm{K} i \mathrm{nM})$ of ligands at DARs, NET and DAT } \\
\cline { 2 - 7 } & D) & $\mathbf{D}_{\mathbf{2}}$ & $\mathbf{D}_{\mathbf{3}}$ & $\mathbf{D}_{\mathbf{4}}$ & D $_{\mathbf{5}}$ & NET & DAT \\
\hline $\mathbf{2}$ & MTA & $5.91 \pm 0.06(1225)$ & $6.76 \pm 0.06(185)$ & $6.01 \pm 0.06(1223)$ & MTA & MTA & MTA \\
\hline 3. & MT & $6.1 \pm 0.1(747)$ & $6.87 \pm 0.08(134)$ & MT & MT & MT & MT \\
\hline
\end{tabular}

MTA $=$ Missed threshold of $50 \%$ inhibition. *The binding affinity results are reported as mean \pm SEM from a minimum of 3 independent assays, each in triplicates.

In summary, 5-chloro-2-(2-(3,4-dihydroisoquinolin-2(1H)-yl)ethyl)-2-methyl-2,3-dihydro-1H-inden-1-one (2) was designed and synthesized to block the racemization of the previously reported alpha des-methyl analog, compound 1c. Following enantiomeric separation, $2 \mathbf{a}$ or (-) 2 has been shown not only to have retained binding affinity to the $5-\mathrm{HT}_{7} \mathrm{R}$ but it has demonstrated significant $\beta$-arrestin biased functional selectivity at the receptor. In fact, while $\mathbf{2 a}$ showed 22 times less activity than 5-HT, for the Gs pathway, it 
showed 28 times higher activity than 5 -HT in the $\beta$-arrestin pathway. This $\beta$-arrestin pathway activity is more potent and more efficacious $\left(2 \mathbf{a} ; \mathrm{EC}_{50}=3.98 \mathrm{nM}\right.$; Emax=78.7\%) than that of the recently published $\beta$ arrestin biased Compound $7\left(\mathrm{EC}_{50}=162 \mathrm{nM}\right.$; Emax=62.7\%) (Table 3). The molecular modeling results revealing interactions of $\mathbf{2} \mathbf{a}$ with appropriate amino acid residues at the orthosteric site of 5-HT $\mathrm{R}_{7}$ suggest that the eutomer $\mathbf{2 a}$ corresponds to the $2 \mathrm{~S}$ isomer. To improve the drug-like characteristics of $\mathbf{2}$, an additional analog, $\mathbf{3}$ with improved hydrophilicity and yet with similar binding affinities as $\mathbf{2}$ has been synthesized and reported in the present work.

\section{Materials and Methods.}

Melting points were determined on a Gallenkamp (UK) apparatus and are uncorrected. All NMR spectra were obtained on a Varian $300 \mathrm{MHz}$ Mercury Spectrometer and the free induction decay (FID) data were processed using Mestrelab's Mnova NMR software (version 8.1) to obtain the reported NMR data. Elemental analyses were carried out by Atlantic Microlab, Inc., Norcross, GA, and are within $0.4 \%$ of theory unless otherwise noted. Flash chromatography was performed using a Teledyne CombiFlash® with Davisil grade 634 silica gel. Starting materials and solvents were obtained from Sigma Aldrich and were used without further purification. All microwave assisted syntheses (MWAS) were carried out using a Biotage Initiator ${ }^{\circledR}$ equipment.

\section{Synthetic Chemistry}

Synthesis of 5-chloro-2-(2-(3,4-dihydroisoquinolin-2(1H)-yl)ethyl)-2-methyl-2,3-dihydro-1H-inden-1one, 2 . 


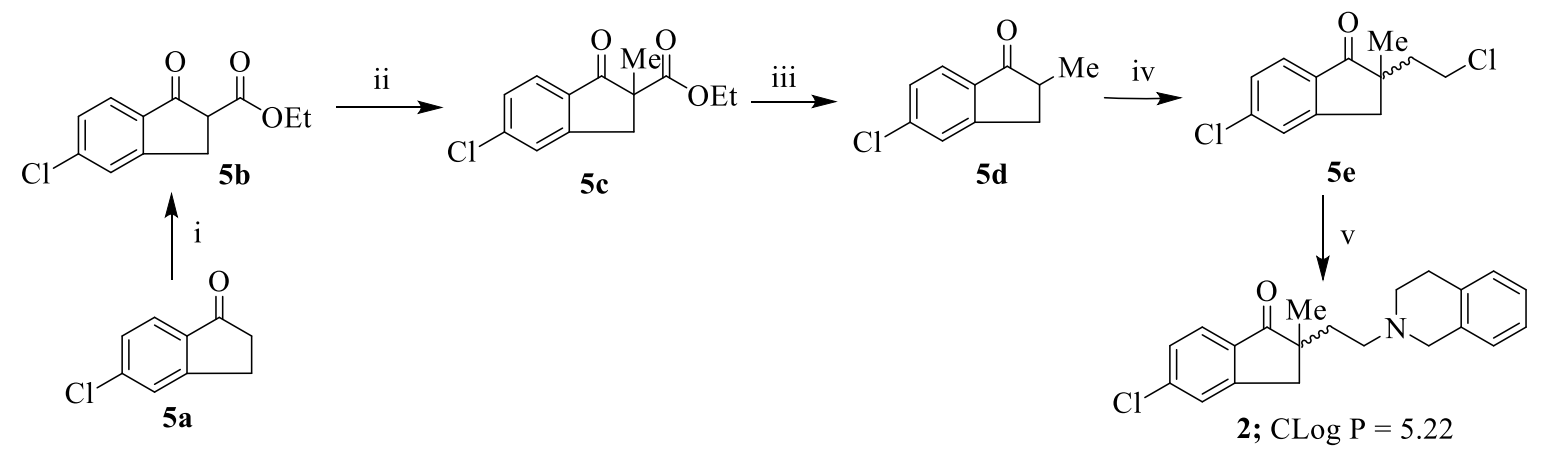

Scheme 1. Synthesis of compound 2

Reagents and conditions: (i) $\mathrm{NaH}$, diethyl carbonate, $0{ }^{\circ} \mathrm{C}$ - rt, $12 \mathrm{~h}$; (ii) $\mathrm{NaH}$, MeI, DMF, rt, 24h; (iii) $\mathrm{Conc} . \mathrm{HCl}$ in AcOH (glacial), MWAS; (iv) NaH, 1-bromo-2-chloroethane, DMF, rt, 24h; (v) 1,2,3,4-tetrahydro-isoquinoline, $\mathrm{K}_{2} \mathrm{CO}_{3}$, KI, toluene, MWAS.

\section{Synthesis of ethyl 5-chloro-1-oxo-2,3-dihydro-1H-indene-2-carboxylate, 5b}

A modified method described by Paccani and co-workers ${ }^{15}$ was followed to access the 5 -substituted $\beta$-keto ester 5b. (Scheme 1). In brief, a solution of 5-chloroindanone 5a, (100 mmol) in diethyl carbonate $(50 \mathrm{~mL})$ was added dropwise to a stirred suspension of sodium hydride $(\mathrm{NaH})(200 \mathrm{mmol}, 60 \%$ in mineral oil previously washed with hexanes) in diethyl carbonate (DEC) $(25 \mathrm{~mL})$ at $0{ }^{\circ} \mathrm{C}$ with stirring (note green coloration). When evolution of gas has ceased, the mixture was allowed to stir at room temperature overnight then diluted with dichloromethane $\left(\mathrm{CH}_{2} \mathrm{Cl}_{2}\right)$ and treated with aqueous acetic acid solution. The aqueous phase was separated and extracted with $\mathrm{CH}_{2} \mathrm{Cl}_{2}$. The combined organic extracts was dried with anhydrous sodium sulfate $\left(\mathrm{Na}_{2} \mathrm{SO}_{4}\right)$ and concentrated under reduced pressure to yield a thick brown crude oil. The crude oil was loaded onto a cartridge and purified on a Combiflash chromatographic equipment using a gradient elution (up to $10 \%$ EtOAc in hexanes) to afford ethyl 5-chloro-1-oxo-2,3-dihydro-1Hindene-2-carboxylate, $\mathbf{5 b}$ as needle-like white crystals. Yield: $89 \% .{ }^{1} \mathrm{H}$ NMR $\left(300 \mathrm{MHz}, \mathrm{CDCl}_{3}\right) \delta 10.47-$ $10.20(\mathrm{~m}, 1 \mathrm{H}), 7.65-7.40(\mathrm{~m}, 3 \mathrm{H}), 4.31-4.13(\mathrm{~m}, 4 \mathrm{H}), 3.71-3.64(\mathrm{~m}, 1 \mathrm{H}), 3.55-3.38(\mathrm{~m}, 2 \mathrm{H}), 3.37-$ $3.22(\mathrm{~m}, 2 \mathrm{H}), 1.35-1.19(\mathrm{~m}, 6 \mathrm{H}) .{ }^{13} \mathrm{C} \mathrm{NMR}\left(75 \mathrm{MHz}, \mathrm{CDCl}_{3}\right) \delta 198.15,168.59,155.11,144.83,135.83$, 
$134.08,131.40,130.78,130.06,129.88,129.80,127.98,125.70,123.71,121.81,102.72,61.83,60.23$, $53.24,32.40,29.91,14.42,14.17$.

[This compound tautomerizes so the number of $\mathrm{H}$ and $\mathrm{C}$ were in some cases double, presented data conformed with reported values per the cited reference]

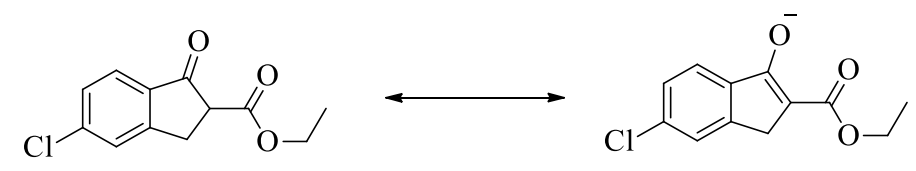

\section{Synthesis of ethyl 5-chloro-2-methyl-1-oxo-2,3-dihydro-1H-indene-2-carboxylate, 5c}

To a suspension of hexane washed $\mathrm{NaH}(60 \%$ in mineral oil, $12 \mathrm{mmol})$ in dry dimethyl formamide (DMF) was added a solution of the 5 -substituted $\beta$-keto ester $\mathbf{5 b}(10 \mathrm{mmol})$ dropwise with stirring (note the green coloration) over $30 \mathrm{~min}$. After the evolution of gas has ceased, methyl iodide (20 mmol) was added dropwise and allowed to stir for 18-24h. After, the reaction was quenched in water (100 mL) and extracted with $\mathrm{CH}_{2} \mathrm{Cl}_{2}(2 \times 100 \mathrm{~mL})$, the organic layers were combined, washed with brine $(100 \mathrm{~mL})$, and dried over $\mathrm{Na}_{2} \mathrm{SO}_{4}$. The resulting solution was concentrated in-vacuo to obtain the crude product intermediate, ethyl 5chloro-2-methyl-1-oxo-2,3-dihydro-1H-indene-2-carboxylate, 5c was obtained in good yield (78\%) as yellow crystals. ${ }^{1} \mathrm{H}$ NMR $\left(300 \mathrm{MHz}, \mathrm{CDCl}_{3}\right) \delta 7.54(\mathrm{~d}, \mathrm{~J}=8.1 \mathrm{~Hz}, 1 \mathrm{H}), 7.34(\mathrm{~s}, 1 \mathrm{H}), 7.22(\mathrm{~d}, \mathrm{~J}=8.5 \mathrm{~Hz}$, 1H), $3.99(\mathrm{q}, \mathrm{J}=7.4 \mathrm{~Hz}, 2 \mathrm{H}), 3.56(\mathrm{~d}, \mathrm{~J}=17.3 \mathrm{~Hz}, 1 \mathrm{H}), 2.85(\mathrm{~d}, \mathrm{~J}=17.3 \mathrm{~Hz}, 1 \mathrm{H}), 1.36(\mathrm{~s}, 3 \mathrm{H}), 1.13-0.99$ (m, 3H). ${ }^{13} \mathrm{C}$ NMR (75 MHz, cdcl3) $\delta 201.71,171.31,154.05,141.58,133.10,128.47,126.60,125.77$, $61.44,56.06,39.52,20.73,13.88$.

\section{Synthesis of 5-chloro-2-methyl-2,3-dihydro-1H-inden-1-one, 5d}

Intermediate 5c was hydrolyzed and decarboxylated to obtain $\mathbf{5 d}$ using a microwave assisted reaction. Briefly, the crude $\beta$-keto ester $\mathbf{5 c}$ was dissolved in $10 \mathrm{~mL}$ of glacial acetic acid and transferred into a $20 \mathrm{~mL}$ Biotage microwave vial equipped with a stirrer. To the solution was added $3 \mathrm{~mL}$ of conc. $\mathrm{HCl}$ and the vial 
was sealed and subjected to microwave heating for $30 \mathrm{~min}$. The vial was then allowed to cool to room temperature and internal pressure released prior to opening. The content was neutralized with saturated sodium bicarbonate $\left(\mathrm{NaHCO}_{3}\right)$ and extracted with $\mathrm{CH}_{2} \mathrm{Cl}_{2}(3 \times 50 \mathrm{~mL})$. The organic layers were pulled, washed with brine, dried (anhydrous $\mathrm{Na}_{2} \mathrm{SO}_{4}$ ), and solvent removed in-vacuo to produce a thick oily crude product. The crude was purified on flash column chromatography using gradient elution (up to $20 \%$ EtOAc in hexanes) to afford the corresponding intermediates $\mathbf{5 d}$ as clear yellowish crystals. Yield: $79 \%$. ${ }^{1} \mathrm{H}$ NMR $\left(300 \mathrm{MHz}, \mathrm{CDCl}_{3}\right) \delta 7.61(\mathrm{~d}, \mathrm{~J}=8.6 \mathrm{~Hz}, 1 \mathrm{H}), 7.38(\mathrm{~s}, 1 \mathrm{H}), 7.28(\mathrm{~d}, \mathrm{~J}=8.0 \mathrm{~Hz}, 1 \mathrm{H}), 3.40-3.25(\mathrm{~m}, 1 \mathrm{H})$, $2.71-2.61(\mathrm{~m}, 2 \mathrm{H}), 1.26(\mathrm{~d}, \mathrm{~J}=7.3 \mathrm{~Hz}, 3 \mathrm{H}) .{ }^{13} \mathrm{C} \mathrm{NMR}\left(75 \mathrm{MHz} \mathrm{CDCl}_{3}\right) \delta 207.84,154.88,141.10,134.75$, $128.12,126.68,125.03,42.09,34.62,16.20$.

\section{Synthesis of 5-chloro-2-(2-chloroethyl)-2-methyl-2,3-dihydro-1H-inden-1-one, 5e}

To a suspension of hexane washed $\mathrm{NaH}(60 \%$ in mineral oil, $12 \mathrm{mmol})$ in dry DMF was added a solution of the 5-chloro-2-methyl-2,3-dihydro-1H-inden-1-one, 5d (10 mmol) dropwise with stirring (note the green coloration) over $30 \mathrm{~min}$. After the evolution of gas has ceased, 1-bromo-2-chloroethane (20 mmol) (scheme 1) was added dropwise and allowed to stir for $24 \mathrm{~h}$. After, the reaction was quenched in water (100 mL) and extracted with $\mathrm{CH}_{2} \mathrm{Cl}_{2}(2 \times 100 \mathrm{~mL})$, the organic layers were combined, washed with brine $(100 \mathrm{~mL})$ and dried over $\mathrm{Na}_{2} \mathrm{SO}_{4}$. The resulting solution was concentrated under reduced pressure to obtain the crude product 5e, as a clear yellowish oil (45\% overall yield). ${ }^{1} \mathrm{H} \mathrm{NMR}\left(300 \mathrm{MHz}, \mathrm{CDCl}_{3}\right) \delta 7.66(\mathrm{~d}, \mathrm{~J}=8.4 \mathrm{~Hz}$, 1H), $7.42(\mathrm{~s}, 1 \mathrm{H}), 7.34(\mathrm{~d}, \mathrm{~J}=8.0 \mathrm{~Hz}, 1 \mathrm{H}), 3.56-3.42(\mathrm{~m}, 2 \mathrm{H}), 3.18(\mathrm{~d}, \mathrm{~J}=16.9 \mathrm{~Hz}, 1 \mathrm{H}), 2.92(\mathrm{~d}, \mathrm{~J}=17.9$

$\mathrm{Hz}, 1 \mathrm{H}), 2.10(\mathrm{t}, \mathrm{J}=8.4 \mathrm{~Hz}, 2 \mathrm{H}), 1.22(\mathrm{~s}, 3 \mathrm{H}) .{ }^{13} \mathrm{C} \mathrm{NMR}\left(75 \mathrm{MHz}, \mathrm{CDCl}_{3}\right) \delta$ 208.15, 153.59, 141.67, $133.70,128.51,126.79,125.55,48.76,40.52,40.48,40.28,23.63$. 


\section{5-chloro-2-(2-(3,4-dihydroisoquinolin-2(1H)-yl)ethyl)-2-methyl-2,3-dihydro-1H-inden-1-one, 2}

\section{Oxalate}

A mixture of 5-chloro-2-(2-chloroethyl)-2-methyl-2,3-dihydro-1H-inden-1-one, 5e (2.05 mmol), THIQ (2.26 mmol), potassium carbonate $\left(\mathrm{K}_{2} \mathrm{CO}_{3} 2.26 \mathrm{mmol}\right)$, and $\mathrm{KI}$ (catalytic amount) in dimethoxyethane (DME, $10 \mathrm{~mL}$ ) was placed in a $20 \mathrm{~mL}$ microwave vial with a stirrer and tightly sealed. The mixture was subjected to microwave heating at $120{ }^{\circ} \mathrm{C}$ for 60 mins. The crude mixture was purified on silica gel by flash chromatography (hexanes: EtOAc gradient up to $70 \%$ EtOAc) to afford the compound as its free base. The free base was converted to the oxalate salt and crystallized from methanol-diethyl ether $\left(\mathrm{MeOH}-\mathrm{Et}_{2} \mathrm{O}\right)$ as white crystals. Yield: $55 \%$, mp: $205-206{ }^{\circ} \mathrm{C} .{ }^{1} \mathrm{H}$ NMR $\left(300 \mathrm{MHz}, \mathrm{DMSO}-d_{6}\right) \delta 11.15$ (s, 2H), $7.77-7.54$ (m, 2H), $7.54-7.37(\mathrm{~m}, 1 \mathrm{H}), 7.28-7.00(\mathrm{~m}, 4 \mathrm{H}), 4.15(\mathrm{~s}, 2 \mathrm{H}), 3.33-3.13(\mathrm{~m}, 3 \mathrm{H}), 3.13-2.84(\mathrm{~m}, 5 \mathrm{H})$, $2.10-1.87(\mathrm{~m}, 2 \mathrm{H}), 1.14(\mathrm{~s}, 3 \mathrm{H}) .{ }^{13} \mathrm{C}$ NMR $\left(75 \mathrm{MHz}, \mathrm{DMSO}-d_{6}\right) \delta 208.33,164.69,154.78,140.65,133.98$, $132.30,130.16,128.88,128.64,127.65,127.50,126.93,126.78,125.80,52.72,52.13,49.40,47.71,32.09$, 31.13, 25.91, 23.70. Anal. Calcd for $\mathrm{C}_{23} \mathrm{H}_{24} \mathrm{ClNO}_{5}$ : C, 64.26; H, 5.63; N, 3.26. Found: C, 63.96; $\mathrm{H}, 5.67 ; \mathrm{N}$, 3.33 .

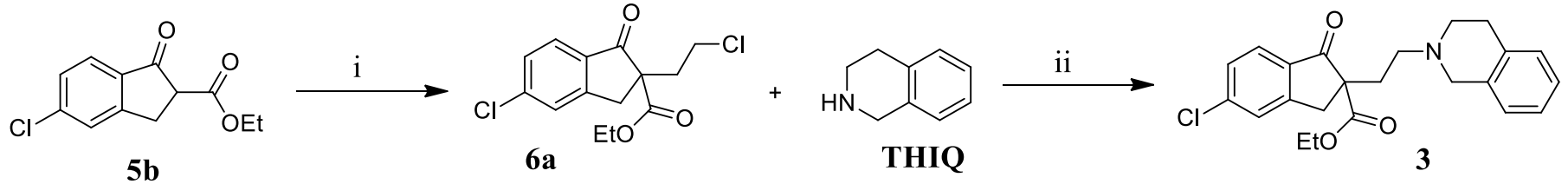

\section{Scheme 2. Synthesis of Analog 3}

Reagents and conditions: (i) $\mathrm{NaH}, \mathrm{DMF}, 1$-bromo-2-chloroethane, rt, 18-24 h. (ii) $\mathrm{PhMe}, \mathrm{NaHCO}_{3}, \mathrm{KI}$, MWAS

Ethyl 5-chloro-2-(2-(3,4-dihydroisoquinolin-2(1H)-yl)ethyl)-1-oxo-2,3-dihydro-1H-indene-2-carboxylate, 3 oxalate 
To a suspension of hexane-washed $\mathrm{NaH}(60 \%$ in mineral oil, $12 \mathrm{mmol})$ in dry DMF was added a solution of the ethyl 5-chloro-1-oxo-2,3-dihydro-1H-indene-2-carboxylate, $\mathbf{5 b}(10 \mathrm{mmol})$ dropwise with stirring (note the green coloration) over $30 \mathrm{~min}$. After the evolution of gas has ceased, 1-bromo-2-chloroethane (20 mmol) (scheme 1) was added dropwise and allowed to stir for 18-24h. After, the reaction was quenched in water (100 mL), extracted with $\mathrm{CH}_{2} \mathrm{Cl}_{2}(2 \times 100 \mathrm{~mL})$, the organic layers were pulled together, washed with brine, and dried over $\mathrm{Na}_{2} \mathrm{SO}_{4}$ and concentrated in-vacuo to obtain the crude product, $6 \mathbf{a}$ which was then used directly in the next step without further purification.

A mixture of alkylating agent, $6 \mathbf{a}(1.66 \mathrm{mmol})$, THIQ $(1.82 \mathrm{mmol}) \mathrm{NaHCO}_{3}(1.82 \mathrm{mmol})$, and $\mathrm{KI}$ (catalytic) in DME or Toluene $(10 \mathrm{~mL})$ was placed in a $20 \mathrm{~mL}$ microwave vial with a stirrer and tightly sealed. The mixture was subjected to microwave heating at $120{ }^{\circ} \mathrm{C}$ for $60 \mathrm{mins}$, allowed to cool to room temperature and the mixture was directly purified on silica gel by flash chromatography (hexanes: EtOAc gradient up to 70\% EtOAc) to afford the compound as a free base. The free base was converted to the oxalate salt and recrystallized from a mixture of $\mathrm{MeOH}-\mathrm{Et}_{2} \mathrm{O}$ as solvent. Yield: $43 \%$, Mp: 161-162 ${ }^{\circ} \mathrm{C} .1 \mathrm{H} \mathrm{NMR}(300 \mathrm{MHz}$, DMSO-d6) $\delta 7.75(\mathrm{~d}, \mathrm{~J}=6.0 \mathrm{~Hz}, 1 \mathrm{H}), 7.63(\mathrm{~d}, \mathrm{~J}=8.1 \mathrm{~Hz}, 1 \mathrm{H}), 7.48(\mathrm{~d}, \mathrm{~J}=8.2 \mathrm{~Hz}, 1 \mathrm{H}), 7.23-7.10(\mathrm{~m}$, 4H), $4.05(\mathrm{dt}, \mathrm{J}=14.2,6.9 \mathrm{~Hz}, 4 \mathrm{H}), 3.66-3.41(\mathrm{~m}, 1 \mathrm{H}), 3.38-2.77(\mathrm{~m}, 7 \mathrm{H}), 2.45-2.13(\mathrm{~m}, 2 \mathrm{H}), 1.06(\mathrm{t}, \mathrm{J}$ $=7.0 \mathrm{~Hz}, 3 \mathrm{H}) .{ }^{13} \mathrm{C}$ NMR: 200.58, 170.36, 163.46, 155.43, 141.10, 133.63, 129, 128.88, 127.63, 127.32, $126.94,126.62,126.16,61.97,58.95,53.24,52.10,49.63,36.29,29.22,26.15,14.23$.

Enantiomeric Separation: The separation of the enantiomers was accomplished using high performance liquid chromatography (HPLC) with a semi-prep scale CHIRALPAK AD-H $1.0 \mathrm{~cm}$ x $25 \mathrm{~cm}$ column, 95:5:0.1 Hex:EtOH:diethylamine (DEA) mobile phase, $4.7 \mathrm{~mL} / \mathrm{min}$ flowrate, and $254 \mathrm{~nm}$ analysis wavelength and was reported previously. [18] 


\section{Biological Evaluation}

\section{Receptor binding affinity studies}

Binding affinities reported in were conducted by the National Institute of Mental Health Psychoactive Drug Screening Program (NIMH-PDSP). Details of the methods and radioligands used for the binding assays were previously reported. [17, 24]

\section{GPCR Tango assays: G-protein independent $\beta$-arrestin recruitment}

Recruitment of $\beta$-arrestin to agonist stimulated 5-HT7R were performed using the "Tango"-type assay described in Barnea et al. [25] with modifications, to evaluate $\mathbf{2 a}$ and $\mathbf{2 b}$. GPCR Tango assay for measuring G-protein independent $\beta$-arrestin recruitment was carried out by the National Institute of Mental Health Psychoactive Drug Screening Program (PDSP) as per their protocol with some modifications in the Tango assay system reported previously.[24] GPCR Tango constructs were codon optimized for better expression in mammalian cell lines and total synthesis was by Blue Heron Biotech (Bothell, WA) with independent sequencing confirmation.[26] HTLA cells (an HEK293 cell line stably expressing a tTA-dependent luciferase reporter and a $ß$-arrestin2-TEV fusion gene) were maintained in DMEM supplemented with $10 \%$ FBS and $2 \mu \mathrm{g} / \mathrm{ml}$ Puromycin and $100 \mu \mathrm{g} / \mathrm{ml}$ Hygromycin. The FLAG tag was designed into the GPCR Tango constructs for confirmation of surface expression and comparison of expression levels. HTLA cells were transfected using calcium phosphate transfection method [27-29] with GPCR tango constructs. Briefly, HTLA cells were subcultured into $10-\mathrm{cm}$ dishes $\left(3 \times 10^{6}\right.$ cells per dish) and incubated overnight. For transfection in each $10-\mathrm{cm}$ dish, $10 \mu \mathrm{g}$ receptor DNA construct in $440 \mu$ l distilled water was mixed with 60 $\mu \mathrm{l}$ of $2 \mathrm{M} \mathrm{CaCl}_{2}$ and the DNA/CaCl 2 solution was then added dropwise into $500 \mu \mathrm{l} 2 \mathrm{x}$ HBS solution (50 mM HEPES, $280 \mathrm{mM} \mathrm{NaCl}, 10 \mathrm{mM} \mathrm{KCl}, 1.5 \mathrm{mM} \mathrm{Na}$ HPO4, pH 7.00) while shaking. The mixture was incubated at room temperature for $10 \mathrm{~min}$, then added to the cells dropwise and incubated overnight. 
Transfected HTLA cells were plated in DMEM supplemented with 1\% dialyzed FBS in Poly-L-Lys (PLL)coated 384-well white clear bottom cell culture plates at a density of 15,000 cells per well $(40 \mu 1)$. Cells were incubated for a minimum of 6 hours or overnight before drug simulation treatments. Drug stimulation solutions prepared in sterile-filtered Tango assay buffer at $5 \mathrm{x}$ concentration were added to cells at $10 \mu \mathrm{l}$ per

well and incubated overnight. Antagonist activity was measured by pre-incubation of drug solutions (6x of the final concentration) with cells for 30 min before addition of $10 \mu \mathrm{l}$ of a final EC80 concentration of reference agonist. The EC80 concentration was determined in separate preliminary dose-response assays. On the day of measurement, medium and drug solutions were removed and BrightGlo reagent (Promega), $20 \mu \mathrm{l}$ per well (diluted 20-fold with Tango assay buffer) were added. Plates were incubated for $20 \mathrm{~min}$ at room temperature in the dark followed by chemiluminescence measurement. The chemiluminescence data was recorded using Luminesence counter and reported as relative luminescence units (RLU).

\section{HEK-5-HT ${ }_{7 \mathrm{~A}}$ / cAMP Functional Assay}

Human embryonic kidney cells were transfected with $10 \mu \mathrm{g}$ h5-HT ${ }_{7 \mathrm{~A}} \mathrm{cDNA}$ using PEI in unsupplemented DMEM. After $5 \mathrm{hr}$, cells were plated at a density of 200,000 cells per well in 48 well plates in DMEM supplemented with $10 \%$ charcoal-stripped FetalClone and pen-strep. The medium was removed about $18 \mathrm{hr}$ later. For agonist assays, $0.9 \mathrm{ml}$ EBSS $\left(116 \mathrm{mM} \mathrm{NaCl}, 22 \mathrm{mM}\right.$ glucose, $15 \mathrm{mM}$ HEPES, $8.7 \mathrm{mM} \mathrm{NaH} \mathrm{PO}_{4}$, $5.4 \mathrm{mM} \mathrm{KCl}, 1.3 \mathrm{mM} \mathrm{CaCl}, 1.2 \mathrm{mM} \mathrm{MgSO}, 1 \mathrm{mM}$ ascorbic acid, $0.5 \mathrm{mM}$ IBMX [3-isobutyl-1-methylxanthine] without $\mathrm{BCS}, \mathrm{pH} 7.4$ at $37^{\circ} \mathrm{C}$ ) was added. After $20 \mathrm{~min}$, the compound was added in a final volume of $1 \mathrm{ml}$, and incubated for $20 \mathrm{~min}$. For antagonists, $0.8 \mathrm{ml}$ EBSS is added, cells were incubated for $10 \mathrm{~min}$, the compound was added, and incubated for $10 \mathrm{~min}$ after which serotonin $(100 \mathrm{nM})$ was added. For all conditions, after 20 min incubation with agonist, the reaction was terminated by aspiration of the buffer, and $0.1 \mathrm{ml}$ trichloroacetic acid was added. Plates were incubated for $2 \mathrm{hr}$ on a rotator. Adenylate cyclase 
activity was measured using a cyclic AMP EIA kit (Cayman). Aliquots (40 $\mu$ l) of each well were diluted to $200 \mu 1$ with EIA buffer from the kit, and $50 \mu 1$ of the dilution was added to the EIA plate. After addition of tracer and monoclonal antibody, the EIA plates were incubated for $18 \mathrm{hr}$ at $4^{\circ} \mathrm{C}$. The reaction was aspirated, plates were washed $5 \times 300 \mu 1$ with wash buffer, and Ellman's reagent was added. After a two-hour incubation in the dark on a rotator, the plates were read at $410 \mathrm{~nm}$. Basal cAMP is subtracted from all values. 5- $\mathrm{HT}_{7 \mathrm{~A}}$ agonists stimulate cAMP formation, maximal stimulation was defined with $10 \mu \mathrm{M}$ serotonin. The maximal drug effect is normalized to maximal serotonin effect in the tables.

\title{
Molecular Modeling
}

The target compounds AS-19, 2a and $\mathbf{2 b}$ were optimized using the LigPrep tool and energy minimized using the OPLS3e force field in Schrodinger's Small-Molecule Drug discovery suite [19-23]. The individual compounds in their protonated forms were docked into the homology model of the $5-\mathrm{HT}_{7} \mathrm{R}$ using the Induced Fit Docking workflow and the results depicted in Figs. 3-4.

\author{
Abbreviations \\ 5-HT: Serotonin \\ 5-HT7R: Serotonin-7 receptor \\ CNS: Central Nervous System \\ DA: Dopamine \\ DAT: Dopamine transporter \\ D2R: Dopamine D2 Receptor \\ DMEM: Dulbecco's Modified Eagle Medium \\ cAMP: Cyclic adenosine monophosphate \\ $\mathrm{EC}_{50}$ : Half maximal effective concentration \\ Emax: Maximal efficacy \\ HPLC: High performance liquid chromatography \\ IFD: Induced Fit Docking \\ MWAS: Microwave assisted synthesis \\ NET: Norepinephrine transporter
}


PDSP: Psychoactive Drug Screening Program

Ro5: Lipinski's rule of five

SERT: Serotonin transporter

\section{ASSOCIATED CONTENT}

\section{AUTHOR INFORMATION}

\section{Corresponding Authors}

*e-mail: seth.ablordeppey@famu.edu

\section{ORCID}

Seth Y. Ablordeppey:

\section{ACKNOWLEDGEMENTS}

This work was financially supported by an NIH/NIGMS SCORE grant number 2SC1GM116724, the Eminent Scholar Chair in Biomedical Sciences support and a Title III Grant to Florida A\&M University. The work was also supported in part by the Pharmaceutical Research Center NIH/NCRR 1C06-RR12512-01

Grant. Ki determinations, receptor binding profiles and functional assays were generously carried out by the National Institute of Mental Health's Psychoactive Drug Screening Program, Contract \# HHSN-271-201300017-C (NIMH PDSP). The NIMH PDSP is directed by Bryan L. Roth MD, PhD at the University of North Carolina at Chapel Hill and Project Officer Jamie Driscoll at NIMH, Bethesda MD, USA. Funding sources acknowledged had no involvement in the study design, data collection and interpretation, or article preparation and submission of this manuscript.

\section{CONFLICT OF INTEREST}

The authors declare that they have no conflict of interest. 


\section{REFERENCES}

1. Bard JA, Zgombick J, Adham N, Vaysse P, Branchek TA, Weinshank RL. Cloning of a novel human serotonin receptor (5-HT7) positively linked to adenylate cyclase. J Biol Chem. 1993;268(31):23422-6. doi:10.1016/S0021-9258(19)49479-9.

2. Bonaventure P, Nepomuceno D, Hein L, Sutcliffe JG, Lovenberg T, Hedlund PB. Radioligand binding analysis of knockout mice reveals 5-hydroxytryptamine(7) receptor distribution and uncovers 8-hydroxy-2(di-n-propylamino)tetralin interaction with alpha(2) adrenergic receptors. Neuroscience. 2004;124(4):90111. doi:10.1016/j.neuroscience.2004.01.014.

3. Blattner KM, Canney DJ, Pippin DA, Blass BE. Pharmacology and Therapeutic Potential of the 5-HT7 Receptor. ACS Chem Neurosci. 2019;10(1):89-119. doi:10.1021/ acschem neuro. 8b00283.

4. Wesolowska A, Tatarczynska E, Nikiforuk A, Chojnacka-Wojcik E. Enhancement of the anti-immobility action of antidepressants by a selective 5-HT7 receptor antagonist in the forced swimming test in mice. European journal of pharmacology. 2007;555(1):43-7. doi:10.1016/j.ejphar.2006.10.001.

5. Lee J, Avramets D, Jeon B, Choo H. Modulation of Serotonin Receptors in Neurodevelopmental Disorders: Focus on 5-HT7 Receptor. Molecules. 2021;26(11):3348. doi:10.3390/molecules26113348.

6. Guscott M, Bristow LJ, Hadingham K, Rosahl TW, Beer MS, Stanton JA et al. Genetic knockout and pharmacological blockade studies of the 5-HT7 receptor suggest therapeutic potential in depression. Neuropharmacology. 2005;48(4):492-502. doi:10.1016/j.neuropharm.2004.11.015.

7. Nikiforuk A. Targeting the Serotonin 5-HT7 Receptor in the Search for Treatments for CNS Disorders: Rationale and Progress to Date. CNS Drugs. 2015;29(4):265-75. doi:10.1007/s40263-015-0236-0.

8. Lovell PJ, Bromidge SM, Dabbs S, Duckworth DM, Forbes IT, Jennings AJ et al. A novel, potent, and selective 5-HT(7) antagonist: (R)-3-(2-(2-(4-methylpiperidin-1-yl)ethyl)pyrrolidine-1-sulfonyl) phen ol (SB-269970). Journal of medicinal chemistry. 2000;43(3):342-5. doi:10.1021/jm991151j.

9. Okubo R, Hasegawa T, Fukuyama K, Shiroyama T, Okada M. Current Limitations and Candidate Potential of 5-HT7 Receptor Antagonism in Psychiatric Pharmacotherapy. Front Psychiatry. 2021;12:623684. doi:10.3389/fpsyt.2021.623684.

10. Brenchat A, Nadal X, Romero L, Ovalle S, Muro A, Sanchez-Arroyos R et al. Pharmacological activation of 5-HT7 receptors reduces nerve injury-induced mechanical and thermal hypersensitivity. Pain. 2010;149(3):483-94. doi:10.1016/j.pain.2010.03.007.

11. Zareifopoulos N, Papatheodoropoulos C. Effects of 5-HT-7 receptor ligands on memory and cognition. Neurobiol Learn Mem. 2016;136:204-9. doi:10.1016/j.nlm.2016.10.011.

12. Hauser SR, Hedlund PB, Roberts AJ, Sari Y, Bell RL, Engleman EA. The 5-HT7 receptor as a potential target for treating drug and alcohol abuse. Front Neurosci. 2014;8:448. doi:10.3389/fnins.2014.00448.

13. McCorvy JD, Butler KV, Kelly B, Rechsteiner K, Karpiak J, Betz RM et al. Structure-inspired design of beta-arrestin-biased ligands for aminergic GPCRs. Nat Chem Biol. 2018;14(2):126-34. doi:10.1038/nchembio.2527.

14. Kim Y, Kim H, Lee J, Lee JK, Min SJ, Seong J et al. Discovery of beta-Arrestin Biased Ligands of 5HT7R. J Med Chem. 2018;61(16):7218-33. doi:10.1021/acs.jmedchem.8b00642.

15. Ofori E, Zhu XY, Etukala JR, Bricker BA, Ablordeppey SY. Synthesis and evaluation of the structural elements in alkylated tetrahydroisoquinolines for binding to CNS receptors. Bioorg Med Chem. 2016;24(22):5730-40. doi:10.1016/j.bmc.2016.09.019.

16. Ofori E, Zhu XY, Etukala JR, Peprah K, Jordan KR, Adkins AA et al. Design and synthesis of dual 5HT1A and 5-HT7 receptor ligands. Bioorg Med Chem. 2016;24(16):3464-71. doi:10.1016/j.bmc.2016.05.053. 
17. Lipinski CA, Lombardo F, Dominy BW, Feeney PJ. Experimental and computational approaches to estimate solubility and permeability in drug discovery and development settings. Advanced drug delivery reviews. 2001;46(1-3):3-26. doi:10.1016/s0169-409x(00)00129-0.

18. Onyameh EK, Bricker BA, Ofori E, Ablordeppey SY. Enantioseparation of 5-chloro-2-\{2-[3,4dihydroisoquinoline-2(1H)-yl]ethyl\}-2-methyl-2,3-dihydro-1H-in den-1-one (SYA 40247), a high-affinity 5-HT7 receptor ligand, by HPLC-PDA using amylose tris-(3, 5- dimethylphenylcarbamate) as a chiral stationary phase. Biomedical chromatography : BMC. 2019;33(9):e4565. doi:10.1002/bmc.4565.

19. Schrödinger LLC. Protein Preparation Wizard. Schrödinger Small-Molecule Drug Discovery Suite. New York, NY Schrödinger, L.L.C.; 2011.

20. Schrödinger LLC. Epik Version 2.2. Schrödinger Small-Molecule Drug Discovery Suite. New York, NY: Schrödinger, L.L.C.; 2011.

21. Schrödinger LLC. Impact Version 5.7. Schrödinger Small-Molecule Drug Discovery Suite. New York, NY: Schrödinger, L.L.C.; 2011.

22. Schrödinger LLC. Prime Version 3.0. Schrödinger Small-Molecule Drug Discovery Suite. New York, NY: Schrödinger, L.L.C.; 2011.

23. Schrödinger LLC. Maestro, Version 9.2. Schrödinger Small-Molecule Drug Discovery Suite. New York, NY: Schrödinger, L.L.C.; 2011.

24. https://pdspdb.unc.edu/pdspWeb/content/PDSP\%20 Protocols\%20II\%202013-03-28.pdf. verified on 127-18

25. Barnea G, Strapps W, Herrada G, Berman Y, Ong J, Kloss B et al. The genetic design of signaling cascades to record receptor activation. Proc Natl Acad Sci U S A. 2008;105(1):64-9. doi:10.1073/ pnas. 0710487105 .

26. Kroeze WK, Sassano MF, Huang XP, Lansu K, McCorvy JD, Giguere PM et al. PRESTO-Tango as an open-source resource for interrogation of the druggable human GPCRome. Nature structural \& molecular biology. 2015;22(5):362-9. doi:10.1038/nsmb.3014.

27. Jordan M, Schallhorn A, Wurm FM. Transfecting mammalian cells: optimization of critical parameters affecting calcium-phosphate precipitate formation. Nucleic acids research. 1996;24(4):596-601. doi:10.1093/nar/24.4.596.

28. Kingston RE, Chen CA, Rose JK. Calcium phosphate transfection. Current protocols in molecular biology. 2003;Chapter 9:Unit 9 1. doi:10.1002/0471142727.mb0901s63.

29. Calcium phosphate-mediated transfection of eukaryotic cells. Nature Methods. 2005;2(4):319-20. doi:10.1038/nmeth0405-319. 